\title{
AUTONOMIA DA VONTADE, AUTONOMIA PRIVADA E O CASO "LULU"
}

\author{
Marco Aurélio Rodrigues da Cunha e Cruz \\ Doutor em Direito Constitucional pela Universidad de \\ Sevilla. Professor do Programa de Pós-Graduação em \\ Direito da Universidade do Oeste de Santa Catarina \\ (UNOESC). \\ mar.cunhaecruz@gmail.com

\begin{abstract}
Jéssica Balbinot
Bacharelanda em Direito da UNOESC. Bolsista de Iniciação Científica do Programa UNIEDU, Santa Catarina. jessibalbinot@gmail.com
\end{abstract}

RESUMO: O uso ofensivo da informática no seio dos direitos fundamentais da personalidade leva à busca de formas de controle/regulação ao acesso de informações sobre o indivíduo e o destino que se faz delas. E um dos exemplos que podem ilustrar estas intercorrências é o "Caso Lulu”. O problema tematizado é o argumento do consentimento, pois sua construção jurídica provém da autonomia da vontade, hoje revisitada pela autonomia privada. O objetivo geral deste artigo é analisar a consistência do argumento do consentimento na interpretação jurídica sobre a autonomia privada quando estão em debate os direitos da personalidade, com foco nos casos do aplicativo Lulu. Procede-se uma pesquisa teórica, de caráter qualitativo, a partir de uma metodologia analítica para abordar os discursos normativo, doutrinário e jurisprudencial mediados para refletir sobre o argumento do consentimento. Foi realizada uma revisão bibliográfica da dogmática, com aplicação da técnica de documentação indireta, abrangendo a pesquisa documental e bibliográfica, para dialogar com os conceitos e com as categorias aptas a identificar e descrever o objeto de pesquisa. A principal conclusão é que pela construção histórica da autonomia da vontade versus autonomia privada, é plausível afirmar que o entendimento do Tribunal de Justiça do Rio Grande do Sul na apelação cível estudada se baseou numa concepção contratual norteada pelo dogma da autonomia da vontade, a qual contraria a lógica do sistema jurídico vigente. O argumento do consentimento, portanto, é inconsistente.

PALAVRAS-CHAVE: Autonomia da vontade; Autonomia privada; Argumento do Consentimento; Dignidade da pessoa humana; Caso Lulu.

\section{Autonomy of the will, Private Autonomy and the "Lulu" case}

ABSTRACT: The use of information technology related to the fundamental rights of the personality leads to the search for ways to control the access of information about the individual and the destiny that is made of them. One of the examples that can illustrate this relationship is the "Lulu Case". The problem is the argument of consent, because its legal configuration comes from the autonomy of the will, now revisited by private autonomy. The goal of this article is to analyze the reflexes of the consent argument in the legal interpretation on private autonomy when the rights of the personality are being debated, focusing on the cases of the Lulu application. This is a theoretical research carried out from an analytical methodology to approach the 
normative, doctrinal and jurisprudential discourses mediated to reflect on the argument of consent. The main conclusion is that through the historical construction of autonomy of will versus private autonomy, it is plausible to affirm that the Rio Grande do Sul Court of Appeal's understanding in the civil appeal studied was based on a contractual conception guided by the dogma of autonomy of the will, which Contrary to the logic of the current legal system. The consent argument, therefore, is inconsistent.

KEYWORDS: Autonomy of the will. Private Autonomy. The Argument of Consent. Human Dignity. The "Lulu" case.

\section{INTRODUÇÃO}

É fato que o ser humano desenvolve diversas potencialidades nas relações de imanência e transcendência com os demais. É neste sentido que são invocados os primordiais bens que hão de ser relacionados pelo sujeito na sua interação com a Sociedade: os bens da personalidade. Para agudizar esta relação/interação, é irrefutável pensá-los dentro do conflito permanente que os bens da personalidade encontram na Sociedade da Informação. A utilidade da rede como fonte de informações e como instrumento de comunicação e aproximação das pessoas é diretamente proporcional à ampliação das possibilidades de vulneração aos direitos e liberdades individuais. $\mathrm{O}$ uso ofensivo da informática no seio dos direitos fundamentais da personalidade leva à busca de formas de controle/regulação ao acesso de informações sobre o indivíduo e o destino que se faz delas. E um dos exemplos que podem ilustrar estas intercorrências é o "Caso Lulu".

Em novembro de 2013, a Luluvise Incorporation lançou o aplicativo “Lulu” para smartphones e tablets que permitia que exclusivamente as mulheres avaliassem, anonimamente, por meio de hashtags pré-definidas ${ }^{1}$, os homens de seu círculo de amizades, atribuindo notas sobre diversos aspectos pessoais (OLHAR DIGITAL, 2015; MANNARA, 2013). Os dados dos perfis dos avaliados eram fornecidos pelo Facebook. Contra a Facebook Serviços Online do Brasil Ltda e a Luluvise Incorporation foram propostas algumas ações judiciais [como em Goiânia-Goiás (CONJUR, 2013) e São Bernardo do Campo-SP (TJSP, 2014, 2015)]. Foi instaurado, inclusive, um inquérito civil público pelo Ministério Público do Distrito Federal e Territórios (MPDFT, 2013), do qual resultou uma ação civil pública, que posteriormente teve sua competência declinada (TJDFT, 2013, 2014). A última das decisões judiciais que se tem notícia sobre o "Caso Lulu” é proveniente do Tribunal de Justiça do Rio Grande do Sul (TJRS, 2016).

Do teor dos três primeiros julgados, algumas controvérsias jurídicas foram levantadas. Importa ressaltar as de direito material, que podem ser agrupadas nos seguintes argumentos: (1) argumento da vedação constitucional ao anonimato (art. $5^{\circ}$, IV, CF-88 ${ }^{2}$ ); (2) argumento da inviolabilidade constitucional e da proteção civil da honra, da vida privada, da intimidade e da imagem (art. 5, X, CF-88 3 ; arts. 11 ao $21, \mathrm{CC}-02^{4}$ ); (3) argumento da relação de consumo (art. $3^{\circ}$,

\footnotetext{
1 Algumas das hashtags pré-definidas pelo próprio aplicativo: “feio arrumadinho, não se interessa por nada, não liga no dia seguinte, dá sono, não fede nem cheira, no style, sem limites, só amigos, should como whith warning, só pensa nisso, esquentadinho, acha que o mundo gira ao seu redor".

2 Constituição da República Federativa do Brasil de 1988 (CF-88): “Art. $5^{\circ}$ Todos são iguais perante a lei, sem distinção de qualquer natureza, garantindo-se aos brasileiros e aos estrangeiros residentes no País a inviolabilidade do direito à vida, à liberdade, à igualdade, à segurança e à propriedade, nos termos seguintes: [...]IV - é livre a manifestação do pensamento, sendo vedado o anonimato;".

3 CF-88: "Art. $5^{\circ}$ Todos são iguais perante a lei, sem distinção de qualquer natureza, garantindo-se aos brasileiros e aos estrangeiros residentes no País a inviolabilidade do direito à vida, à liberdade, à igualdade, à segurança e à propriedade, nos termos seguintes: [...]X - são invioláveis a intimidade, a vida privada, a honra e a imagem das pessoas, assegurado o direito a indenização pelo dano material ou moral decorrente de sua violação;”.

4 Lei n. 10.406, de 10 de Janeiro de 2002 (CC-02): “CAPÍTULO II - DOS DIREITOS DA PERSONALIDADE
} 
CDC- $90^{5}$ ), pois a partir deste reconhecimento pode se imputar como inadequadas ou insuficientes as informações sobre a fruição e riscos do serviço por eles prestados (art. 14, CDC-90 6 ), além de se intitular o termo e condições de uso como mero contrato de adesão (art. 54, CDC-90 ${ }^{7}$ ).

Há de se notar que todos estes argumentos estão envolvidos por um fato jurídico comum: a transmissão dos dados pessoais e imagens pelo Facebook ao aplicativo Lulu. As decisões julgaram, sumária ou definitivamente, que esta transmissão é ilícita, pois inconsentida. Contudo, a última das decisões judiciais, a proferida pelo Tribunal de Justiça do Rio Grande do Sul, não entendeu assim. Afirmou que ao se cadastrar no Facebook o usuário consentiu que as informações relativas ao nome, sexo e fotos de perfil poderiam ser acessadas por qualquer pessoa através da rede mundial de computadores e que as informações transmitidas do perfil do autor são resultantes de dados públicos, conforme termos de uso da rede social. Pelo consentimento expresso do titular, portanto, não haveria que se falar em compartilhamento de informações indevidas (TJRS, 2016). O TJRS utilizou o argumento do consentimento de publicidade dos dados pessoais para considerar como lícito o compartilhamento de informações pessoais dos usuários do Facebook.

Diante deste contexto, o problema tematizado é o argumento do consentimento, pois sua construção jurídica provém da autonomia da vontade, hoje revisitada pela autonomia privada. $\mathrm{O}$ artigo utiliza como referencial teórico os conceitos de "consistência" e de "coerência" extaídos do texto "Fundamentação jurídica, sistema e coerência" de Robert Alexy (2006) para examinar as decisões judiciais mais destacadas. O objetivo geral é analisar a consistência do argumento do consentimento na interpretação jurídica sobre a autonomia privada quando estão em debate os direitos da personalidade, com foco nos casos do aplicativo Lulu. Os objetivos específicos deste artigo são dois:

(i) depurar a coerência dos argumentos jurídicos utilizados pelo TJRS na apelação cível n. 0158308-71.2016.8.21.7000 para declarar como lícita a transmissão de informações pessoais entre Facebook e Lulu;

Art. 11. Com exceção dos casos previstos em lei, os direitos da personalidade são intransmissíveis e irrenunciáveis, não podendo o seu exercício sofrer limitação voluntária. [...]”.

5 Lei $n^{\circ} 8.078$, de 11 de Setemebro de 1990 (CDC-90): “Art. $3^{\circ}$ Fornecedor é toda pessoa física ou jurídica, pública ou privada, nacional ou estrangeira, bem como os entes despersonalizados, que desenvolvem atividade de produção, montagem, criação, construção, transformação, importação, exportação, distribuição ou comercialização de produtos ou prestação de serviços. $\S 1^{\circ}$ Produto é qualquer bem, móvel ou imóvel, material ou imaterial. $\S 2^{\circ}$ Serviço é qualquer atividade fornecida no mercado de consumo, mediante remuneração, inclusive as de natureza bancária, financeira, de crédito e securitária, salvo as decorrentes das relações de caráter trabalhista".

${ }^{6}$ CDC-90: "Art. 14. O fornecedor de serviços responde, independentemente da existência de culpa, pela reparação dos danos causados aos consumidores por defeitos relativos à prestação dos serviços, bem como por informações insuficientes ou inadequadas sobre sua fruição e riscos. $\S 1^{\circ} \mathrm{O}$ serviço é defeituoso quando não fornece a segurança que o consumidor dele pode esperar, levando-se em consideração as circunstâncias relevantes, entre as quais: I - o modo de seu fornecimento; II - o resultado e os riscos que razoavelmente dele se esperam; III - a época em que foi fornecido. $\S$ $2^{\circ} \mathrm{O}$ serviço não é considerado defeituoso pela adoção de novas técnicas. $\S 3^{\circ} \mathrm{O}$ fornecedor de serviços só não será responsabilizado quando provar: I - que, tendo prestado o serviço, o defeito inexiste; II - a culpa exclusiva do consumidor ou de terceiro. $\S 4^{\circ}$ A responsabilidade pessoal dos profissionais liberais será apurada mediante a verificação de culpa".

7 CDC-90: "Art. 54. Contrato de adesão é aquele cujas cláusulas tenham sido aprovadas pela autoridade competente ou estabelecidas unilateralmente pelo fornecedor de produtos ou serviços, sem que o consumidor possa discutir ou modificar substancialmente seu conteúdo. $\S 1^{\circ} \mathrm{A}$ inserção de cláusula no formulário não desfigura a natureza de adesão do contrato. $\S 2^{\circ}$ Nos contratos de adesão admite-se cláusula resolutória, desde que a alternativa, cabendo a escolha ao consumidor, ressalvando-se o disposto no $\S 2^{\circ}$ do artigo anterior. $\S 3$ o Os contratos de adesão escritos serão redigidos em termos claros e com caracteres ostensivos e legíveis, cujo tamanho da fonte não será inferior ao corpo doze, de modo a facilitar sua compreensão pelo consumidor. $\S 4^{\circ}$ As cláusulas que implicarem limitação de direito do consumidor deverão ser redigidas com destaque, permitindo sua imediata e fácil compreensão". 
(ii) analisar a consistência do argumento do consentimento pelo titular do uso dos seus direitos da personalidade.

A relevância do tema demanda uma investigação sobre os conceitos de dignidade da pessoa humana e de autonomia privada. Neste sentido, a orientação do artigo se volta para as concepções de autonomia da vontade (RODRIGUES JÚNIOR, 2012; FACHIN, 2012; BERTI, 2014; MARQUES, 2016), autonomia privada (PRATA, 1982; FERRI, 2001; BORGES, 2005a, 2005b; NETO, 2011) e de dignidade da pessoa humana (SARLET, 2004; BARROSO, 2013). Procede-se uma pesquisa teórica, de caráter qualitativo, a partir de uma metodologia analítica para abordar os discursos normativo, doutrinário e jurisprudencial mediados para refletir sobre o argumento do consentimento. Foi realizada uma revisão bibliográfica da dogmática, com aplicação da técnica de documentação indireta, abrangendo a pesquisa documental e bibliográfica, para dialogar com os conceitos e com as categorias aptas a identificar e descrever o objeto de pesquisa. Para alcançar os objetivos, no primeiro tópico são detalhadas as razões fáticas e sublinhados os fundamentos jurídicos declinados nos citados casos que envolveram o aplicativo Lulu, com especial atenção para a apelação cível n. 0158308-71.2016.8.21.7000. Faz-se uma análise da coerência da estrutura de fundamentação (o iter argumentativo) das razões de decidir deste julgado. Posteriormente, investiga-se o locus científico dos conceitos de dignidade da pessoa humana, de autonomia da vontade e de autonomia privada, para tecer as considerações sobre a consistência do argumento do consentimento utilizado na interpretação da apelação cível n. 0158308-71.2016.8.21.7000, do TJRS. Ao final são feitas as conclusões.

\section{APRESENTAÇÃO DOS 4 CASOS DO APLICATIVO LULU}

Em ação cautelar proposta em Goiás em 2013, o autor alegou ofensas aos seus direitos da personalidade por utilização não autorizada de sua imagem com a finalidade de lhe atingir a honra. A despeito de ter solicitado a exclusão da sua conta no Facebook, seu perfil permanecia ativo no aplicativo Lulu. A decisão liminar vislumbrou a plausibilidade dos argumentos jurídicos invocados, baseando-se na vedação constitucional ao anonimato (art. $5^{\circ}$, IV, CF-88), na inviolabilidade da honra e da imagem (art. 5, X, CF-88), na proteção civil dos direitos da personalidade (arts. 11 ao 21, CC-02), além de ver iminentes violações irreparáveis a estes direitos se novas avaliações continuassem a ser feitas no tal aplicativo. (CONJUR, 2013).

Ainda em 2013, por não ter obtido resposta ao inquérito civil público, o MPDFT ajuizou ação civil pública (ACP) por vulnerações aos direitos da personalidade dos consumidores, com pedido de liminar para a suspensão imediata do compartilhamento de dados entre o Facebook e Luluvise. A ACP teve como fundamentos normativos a Constituição Federal, o Código Civil e o Código de Defesa do Consumidor. Requereu-se: a exclusão dos dados e imagens dos que não haviam consentido previamente em ser avaliados; que se vedasse a avaliação anônima, além do dano moral coletivo. (MPDFT, 2013). O juízo de primeiro grau entendeu que a proteção dos direitos do artigo $5 .^{\circ}$ deveria ser postulada por cada uma das pessoas que concretamente experimentaram a violação de seus atributos da personalidade, obstada, portanto, a legitimidade ativa

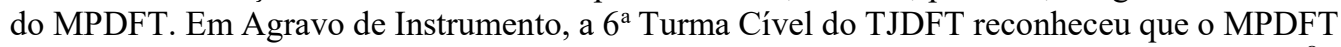
era legítimo, pois implicados no caso direitos individuais homogêneos (art. 81, III, CDC-90 ${ }^{8}$ ).

\footnotetext{
8 CDC-90: “Art. 81. A defesa dos interesses e direitos dos consumidores e das vítimas poderá ser exercida em juízo individualmente, ou a título coletivo. Parágrafo único. A defesa coletiva será exercida quando se tratar de: I - interesses ou direitos difusos, assim entendidos, para efeitos deste código, os transindividuais, de natureza indivisível, de que sejam titulares pessoas indeterminadas e ligadas por circunstâncias de fato; II - interesses ou direitos coletivos, assim
} 
Observou que a manutenção das avaliações anônimas e da publicação destas sem o consentimento ou conhecimento dos usuários provocaria uma ofensa ao direito à intimidade, além de afrontar a vedação constitucional ao anonimato (art. 5, IV, CF-88). Concluiu que "não pode ser mantida, ao menos em cognição sumária, a possibilidade de avaliações de pessoas sem que essas tenham o conhecimento do seu teor e do seu subscritor". (TJDFT, 2013).

Na sentença da ação julgada em São Bernardo do Campo, em 2014, o juízo certificou que o aplicativo Lulu, sem autorização dos usuários, captou perfis masculinos do Facebook que receberam do público feminino avaliações e notas, cuja a maioria dos significados ofendia a honra e a imagem. Verificou que o Facebook confessou que tais perfis foram compartilhados da sua plataforma e que o próprio aplicativo Lulu, nos seus termos de uso, admitia retirar do Facebook os dados pessoais dos avaliados. Neste sentido, adota um argumento consumerista, com o qual inicia suas razões de decidir. Imputou ao Facebook e ao Lulu a qualidade de fornecedores de serviço (art. $3^{\circ}$, CDC-90), solidários nesta relação de consumo. Apontou que houve insuficiência ou que foram inadequadas as informações sobre a fruição e riscos do serviço por eles prestados (art. 14, CDC-90). Ademais, refutou o argumento de anuência do autor, que consistia na afirmação de que ao firmar o termo e condições de uso do Facebook o autor havia cedido voluntariamente suas imagens e seus dados pessoais. Pontuou-se que pois tal pacto não autoriza o fornecedor a usá-lo economicamente para violar a intimidade, a vida privada, a honra e a imagem das pessoas, pois tais bens são protegidos como direitos individuais fundamentais pela Constituição (art. $5^{\circ}, \mathrm{X}, \mathrm{CF}-88$ ). A sentença afirma que o termo e condições de uso é mero contrato de adesão, onde as cláusulas são estipuladas unilateralmente pelo fornecedor de produtos e serviços (art. 54, CDC-90), "que não rompe o princípio fundamental da República da dignidade da pessoa humana" (art. $3^{\circ}$, III, CF- $88^{9}$ ). Além disso, reputa as condutas do Facebook e do Lulu como ilícitas pois: o aplicativo prima pelo anonimato, vedado pela Constituição Federal (art. $5^{\circ}, \mathrm{IV}, \mathrm{CF}-88$ ); as avaliações por hashstags pré-definidas pelo aplicativo são potencialmente violadoras à honra e à imagem dos avaliados. Observou, portanto, ser cabível a indenização por dano moral pela violação dos direitos da personalidade praticada pelo Facebook e pelo Lulu, condenando-os ao pagamento de $\mathrm{R} \$ 20.000 .00$ (vinte mil reais) (TJSP, 2014). A segunda instância negou provimento à apelação da Luluvise Incorporation, baseando-se nos mesmos fundamentos da sentença. (TJSP, 2015).

Em uma indenizatória por danos morais, protocolada em 2013 ante a Comarca de MarauRS, alegou-se que o Facebook forneceu ao aplicativo "Lulu" dados e informações que violaram a intimidade, a vida privada, a honra e a imagem do autor. Ressaltou-se o fato de não ter havido autorização, além da tentativa, sem êxito, de solicitar o cancelamento do cadastro/inscrição. $\mathrm{O}$ Facebook, em contestação, alegou sua ilegitimidade passiva, bem como ausência de comprovação dos fatos constitutivos de direito do autor, e que o próprio usuário aderiu aos termos e condições de uso do seu site. Alega ainda descabimento de indenização por danos morais e culpa exclusiva do terceiro, Luluvise Incorporation. Citada, a Toweb Brasil Ltda sustentou sua ilegitimidade passiva. No mérito, discorreu acerca da atividade dos provedores de domínios e da sua não responsabilização pelo conteúdo inserido nos domínios que por eles são registrados.

A sentença deu parcial procedência, condenando o Facebook e a Luluvise. (TJRS, 2014). Em sua fundamentação de 9 de setembro de 2014, o juízo de primeira instância repeliu a alegação

entendidos, para efeitos deste código, os transindividuais, de natureza indivisível de que seja titular grupo, categoria ou classe de pessoas ligadas entre si ou com a parte contrária por uma relação jurídica base; III - interesses ou direitos individuais homogêneos, assim entendidos os decorrentes de origem comum".

9 CF-88: "Art. $1^{\circ}$ A República Federativa do Brasil, formada pela união indissolúvel dos Estados e Municípios e do Distrito Federal, constitui-se em Estado Democrático de Direito e tem como fundamentos: [...] III - a dignidade da pessoa humana;". 
de ilegitimidade passiva do Facebook, por considerar de essencial importância a sua participação como transmissor dos perfis para o funcionamento do aplicativo. Refutou, também, o argumento do consentimento do autor aos termos de uso aliada à publicidade dos dados do perfil e da imagem do autor. Afirmou que apesar de concordar com a divulgação da imagem e de seus dados ao se cadastrar, este consentimento não autoriza "de maneira automática e irrestrita, que suas informações pessoais sejam utilizadas de qualquer forma, em qualquer outro site ou aplicativo, muito menos de forma depreciativa, como é o que se verifica com relação ao aplicativo Lulu". Pela ausência da concordância, conhecimento e consentimento prévio do titular dos dados e informações pessoais, reconheceu a ilicitude das condutas do Facebook e do Lulu. Entendeu sem aplicabilidade jurídica o argumento do consentimento da publicidade dos dados e imagens do perfil do autor, considerando o Facebook responsável pela transmissão. Verificou que houve violação à intimidade, à honra e à imagem (art. $5, \mathrm{X}, \mathrm{CF}-88)$ e vulneração à proteção civil dos direitos da personalidade (arts. 11 ao 21, CC-02). (TJRS, 2014).

O TJRS decretou a nulidade do processo por ausência de citação válida de uma das rés, desconstituindo a sentença proferida. Homologou-se a desistência da ação com relação à Luluvise Incorporation. A sentença de 18 de novembro de 2015 utilizou os mesmos fundamentos para julgar parcialmente procedente e condenar o Facebook ao pagamento de R \$3.500,00 (três mil e quinhentos reais) (TJRS, 2015). O Facebook interpôs recurso.

A $10^{a}$ Câmara Cível do TJRS, por unanimidade, deu provimento à apelação, julgando pela inexistência de responsabilidade do Facebook. O acórdão adotou, na integralidade, o relatório da primeira instância. Na fundamentação, reproduziu grande parte de outra decisão proferida pelo próprio Tribunal, entendida como análoga. As foram razões as seguintes: (i) é aplicável o Código de Defesa do Consumidor, com o reconhecimento da relação de consumo. A expressão legal "mediante remuneração" não pode ser confundida pela ausência de onerosidade ao consumidor; (ii) o autor não comprovou o compartilhamento dos dados entre Facebook e Lulu, pois o aplicativo importa dados de outras redes (art. 333, I, CPC-73 ${ }^{10}$ ); (iii) ainda que comprovado o compartilhamento, o argumento do consentimento foi preponderante. O acórdão adere ao alegado das empresas de que o termo de uso do Facebook estipula que os dados pessoais e as imagens serão públicos e que o Lulu não divulgou dados de caráter privativo, capazes de ofender o requerente. Assim, não há ilegalidade ou compartilhamento indevido de dados pelo Facebook; iv) inexiste prova de que o Facebook seja parceiro empresarial da Luluvise, ou que obtenha lucro com o compartilhamento de dados com o aplicativo (art. 333, I, CPC-73) ${ }^{11}$. No mesmo sentido, há um julgado das Turmas Recursais do Estado do Rio de Janeiro do processo $\mathrm{n}^{\circ} 0075614$ 49.2013.8.19.0002.

Antes de avançar para o objeto deste artigo, pode-se apontar uma incoerência argumentativa do teor das razões do TJRS com relação à estrutura da fundamentação do acórdão. Para Robert Alexy (2006), os conceitos de coerência e consistência hão de ser diferenciados. Uma tese consistente é aquela que não evidencia uma contradição lógica. O conceito de coerência pode de ser forjado de modo que contemple a consistência como lado negativo da coerência, isto é, que o conceito de coerência resida quando não ocorra inconsistências. Mas Alexy (2006) prefere que tal conceito seja relacionado exclusivamente a conexões positivas. Estas conexões positivas tem a ver com as relações de fundamentação. E por isso pugna que "Quanto melhor é a estrutura da fundamentação de uma classe de declarações tanto mais coerente é essa classe de

\footnotetext{
${ }^{10}$ Lei n. 5.869 , de 11 de Janeiro de 1973 (CPC-73): "Art. 333. O ônus da prova incumbe: I - ao autor, quanto ao fato constitutivo do seu direito;"'.

${ }^{11}$ O julgamento foi em 2 de Junho de 2016, contudo o acórdão não utilizou o dispositivo normativo correspondente da lei em vigência: Lei 13.105 de 2015 (art. 1.045 c/c 1.046).
} 
declarações". O termo "declarações" inclui as declarações normativas e valorativas. A determinação da coerência pode ser relacionada com os sistemas de normas e ordenamentos de valores. Alexy (2006) detalha os conceitos de fundamentação, de estrutura de fundamentação e de grau ou medida com que os critérios de coerência são cumpridos. O conceito de fundamentação é concebido "de maneira que uma declaração $p$ fundamenta uma declaração $q$ exatamente então, quando $q$ nem sozinho de $p$ nem de $p$ em união com outras premissas resulta logicamente" (ALEXY, 2006, p.297-310) . A estrutura de fundamentação se relaciona com a "classe de das propriedades formais de todas as relações de fundamentação que existem dentro da classe de declarações, a cada vez considerada". Admite que os critérios de coerência se caracterizam pelo fato de serem possíveis de ser cumpridos em graus diferentes e que podem colidir. A característica da estrutura de fundamentação, portanto, "determina-se segundo a medida na qual os critérios de coerência são cumpridos” (ALEXY, 2006, p. 297-310).

Alexy (2006) triparte os critérios de coerência em: a) os relacionados imediatamente com as propriedades de estrutura da fundamentação de um sistema de declarações; b) os que se centram nas propriedades dos conceitos empregados em um sistema de declarações; c) os concernentes às propriedades do âmbito do objeto de um sistema. Os dois últimos critérios de coerência dizem respeito às propriedades da estrutura de fundamentação.

Quanto às propriedades da estrutura de fundamentação, Alexy (2006) faz a conexão entre

(1) o número das relações de fundamentação, pois é uma exigência mínima de coerência que entre as declarações de um sistema haja relações de fundamentação: "quanto mais declarações de um sistema são fundamentadas por uma outra declaração desse sistema, tanto mais coerente é o sistema" e que "Devem ser justificadas tantas declarações quanto possível de um sistema por outras declarações desse sistema";

(2) a extensão da corrente de fundamentação, pois a coerência de um sistema depende da extensão e dos números das correntes de fundamentação, pois: "quanto mais extensas são as correntes de fundamentação, que pertencem a um sistema, tanto mais coerente é o sistema";

(3) o enlace das correntes de fundamentação, pois importa para os sistemas normativos que a fundamentação de declarações mais gerais crie a possibilidade do enlace de correntes de fundamentação, relativamente mais especiais, pois: "quanto mais correntes de fundamentação têm uma premissa de partida comum, tanto mais coerente é o sistema" e "quanto mais correntes de fundamentação têm uma conclusão comum, tanto mais coerente é o sistema"; a

(4) ponderação dos fundamentos, quando há uma colisão de princípios, mas no caso Lulu não foi aventada esta colisão;

(5) a fundamentação recíproca empírica, analítica e normativa, pois quantos mais fundamentações recíprocas em um sistema, tanto mais coerente ele será ocasionando um "equilíbrio reflexivo" entre elas.

Alexy (2006) ainda aponta a propriedade dos conceitos de uma teoria e as propriedades do âmbito do objeto. Este artigo se pautará no conceito de coerência apenas no aspecto da estruturação da fundamentação, pois não se está a avaliar sistemas ou teorias e sim dois dos acórdãos: a decisão do TJRS (2016) e o julgado do TJSP (2015). O motivo eleito para a comparação se dá por dois critérios: a colegialidade das decisões e a instância em que chegaram. Além disso, há uma convergência em uma declaração normativa geral nestes tribunais: ambos reconhecem o "argumento consumerista", ou seja, a existência da relação de consumo entre o autor da ação e 
os fornecedores Facebook e Luluvise Corporation (art. $2^{\circ}$ e $3^{\circ}, \mathrm{CDC}-90^{12}$ ). Mas a partir daí há uma divergência entre os dois Tribunais nas estruturas de fundamentação do argumento consumerista quanto:

(1) ao número das relações de fundamentação;

(2) à extensão da corrente de fundamentação;

(3) ao enlace das correntes de fundamentação e

(4) à fundamentação recíproca.

O TJSP utiliza 6 correntes de fundamentação: responsabilidade solidária; informação inadequada/insuficiente; contrato de adesão; dignidade da pessoa humana; inviolabilidade dos direitos da personalidade; vedação ao anonimato. Ao declarar que há na lide a premissa da relação de consumo (declaração normativa geral), utiliza 3 correntes de fundamentação com o mesmo argumento consumerista: 1-imputa a solidariedade do Facebook e do Lulu nesta relação de consumo (arts. $7^{\circ}$, pár. único; $18,19,25, \S 1^{\circ}, \mathrm{CDC}-90^{13}$ ); 2-grifa a insuficiência ou inadequação

${ }^{12}$ CDC-90: Art. $2^{\circ}$ Consumidor é toda pessoa física ou jurídica que adquire ou utiliza produto ou serviço como destinatário final. $[\ldots]$

Art. $3^{\circ}$ Fornecedor é toda pessoa física ou jurídica, pública ou privada, nacional ou estrangeira, bem como os entes despersonalizados, que desenvolvem atividade de produção, montagem, criação, construção, transformação, importação, exportação, distribuição ou comercialização de produtos ou prestação de serviços.

${ }^{13}$ CDC-90: "Art. $7^{\circ}$ Os direitos previstos neste código não excluem outros decorrentes de tratados ou convenções internacionais de que o Brasil seja signatário, da legislação interna ordinária, de regulamentos expedidos pelas autoridades administrativas competentes, bem como dos que derivem dos princípios gerais do direito, analogia, costumes e eqüidade. Parágrafo único. Tendo mais de um autor a ofensa, todos responderão solidariamente pela reparação dos danos previstos nas normas de consumo.

“Art. 18. Os fornecedores de produtos de consumo duráveis ou não duráveis respondem solidariamente pelos vícios de qualidade ou quantidade que os tornem impróprios ou inadequados ao consumo a que se destinam ou lhes diminuam o valor, assim como por aqueles decorrentes da disparidade, com a indicações constantes do recipiente, da embalagem, rotulagem ou mensagem publicitária, respeitadas as variações decorrentes de sua natureza, podendo o consumidor exigir a substituição das partes viciadas. $\S 1^{\circ}$ Não sendo o vício sanado no prazo máximo de trinta dias, pode o consumidor exigir, alternativamente e à sua escolha: I - a substituição do produto por outro da mesma espécie, em perfeitas condições de uso; II - a restituição imediata da quantia paga, monetariamente atualizada, sem prejuízo de eventuais perdas e danos; III - o abatimento proporcional do preço. $\S 2^{\circ}$ Poderão as partes convencionar a redução ou ampliação do prazo previsto no parágrafo anterior, não podendo ser inferior a sete nem superior a cento e oitenta dias. Nos contratos de adesão, a cláusula de prazo deverá ser convencionada em separado, por meio de manifestação expressa do consumidor. $\S 3^{\circ} \mathrm{O}$ consumidor poderá fazer uso imediato das alternativas do $\S 1^{\circ}$ deste artigo sempre que, em razão da extensão do vício, a substituição das partes viciadas puder comprometer a qualidade ou características do produto, diminuir-lhe o valor ou se tratar de produto essencial. $\S 4^{\circ}$ Tendo o consumidor optado pela alternativa do inciso I do $\S 1^{\circ}$ deste artigo, e não sendo possível a substituição do bem, poderá haver substituição por outro de espécie, marca ou modelo diversos, mediante complementação ou restituição de eventual diferença de preço, sem prejuízo do disposto nos incisos II e III do $\S 1^{\circ}$ deste artigo. $\S 5^{\circ}$ No caso de fornecimento de produtos in natura, será responsável perante o consumidor o fornecedor imediato, exceto quando identificado claramente seu produtor. $\S 6^{\circ}$ São impróprios ao uso e consumo: I - os produtos cujos prazos de validade estejam vencidos; II - os produtos deteriorados, alterados, adulterados, avariados, falsificados, corrompidos, fraudados, nocivos à vida ou à saúde, perigosos ou, ainda, aqueles em desacordo com as normas regulamentares de fabricação, distribuição ou apresentação; III - os produtos que, por qualquer motivo, se revelem inadequados ao fim a que se destinam".

“Art. 19. Os fornecedores respondem solidariamente pelos vícios de quantidade do produto sempre que, respeitadas as variações decorrentes de sua natureza, seu conteúdo líquido for inferior às indicações constantes do recipiente, da embalagem, rotulagem ou de mensagem publicitária, podendo o consumidor exigir, alternativamente e à sua escolha: I - o abatimento proporcional do preço; II - complementação do peso ou medida; III - a substituição do produto por outro da mesma espécie, marca ou modelo, sem os aludidos vícios; IV - a restituição imediata da quantia paga, monetariamente atualizada, sem prejuízo de eventuais perdas e danos. $\S 1^{\circ}$ Aplica-se a este artigo o disposto no $\S 4^{\circ}$ do artigo anterior. $\S 2^{\circ} \mathrm{O}$ fornecedor imediato será responsável quando fizer a pesagem ou a medição e o instrumento utilizado não estiver aferido segundo os padrões oficiais".

“Art. 25. É vedada a estipulação contratual de cláusula que impossibilite, exonere ou atenue a obrigação de indenizar prevista nesta e nas seções anteriores. $\S 1^{\circ}$ Havendo mais de um responsável pela causação do dano, todos responderão 
de informações sobre a fruição e riscos do serviço por eles prestados (art. 14, CDC-90); 3-afirma que o termo e condições de uso é mero contrato de adesão, onde as cláusulas são estipuladas unilateralmente pelo fornecedor de produtos e serviços (art. 54, CDC-90). Das 6 correntes de fundamentação, a extensão de 3 contêm o argumento consumerista (declaração normativa geral), o que representa $50 \%$ das correntes de fundamentação do acórdão paulista. Não obstante, 5 são os enlaces das correntes de fundamentação que partem do argumento consumerista. O TJSP observa que o termo e condições de uso não autoriza o fornecedor a usá-lo economicamente para violar a intimidade, a vida privada, a honra e a imagem das pessoas, pois tais bens são protegidos como direitos individuais fundamentais pela Constituição (art. $5^{\circ}, \mathrm{X}, \mathrm{CF}-88$ ); declara que o termo e condições de uso é mero contrato de adesão (art. 54, CDC-90), o qual não prevalece sobre a dignidade da pessoa humana (art. $3^{\circ}$, III, CF-88). A única corrente de fundamentação desprovida deste enlace é a vedação ao anonimato (art. $5^{\circ}, \mathrm{IV}, \mathrm{CF}-88$ ), o que deduz um 83,33\% de enlace entre correntes de fundamentação. E mais. Há fundamentação recíproca entre o argumento consumerista (declaração normativa geral de existência de relação de consumo) e 3 declarações especiais (responsabilidade solidária; informação inadequada/insuficiente; contrato de adesão), o que também resulta em $50 \%$ de reciprocidade das correntes de fundamentação e um equilíbrio reflexivo.

Por outro lado, TJRS adota o argumento consumerista (declaração normativa geral), mas não utiliza a lógica das relações de consumo para as correntes de fundamentação de sua decisão. O TJRS utiliza 3 correntes de fundamentação: não comprovação de compartilhamento; consentimento do autor aos termos de uso; inexistência de prova da parceria empresarial. Duas correntes de fundamentação se voltam para o ônus probatório de dois fatos distintos (não comprovação de compartilhamento; inexistência de prova da parceria empresarial). A outra corrente de fundamentação utiliza o argumento do consentimento e da publicidade dos dados pessoais. As 3 correntes de fundamentação não guardam relações de fundamentação (fática); nenhuma destas 3 pertence ao argumento consumerista. Disso decorre ser zero a extensão das correntes de fundamentação baseadas no argumento consumerista (declaração geral normativa). Há enlace entre duas correntes de fundamentação quanto à inexistência de provas (do compartilhamento + da parceria empresarial). Apesar de não se relacionarem faticamente, tampouco se reportarem ao argumento consumerista (declaração geral normativa), há uma mesma fundamentação de texto normativo entre as duas correntes de fundamentação (art. 333, I, CPC-73), do que se deduz que $66,66 \%$ de enlace entre as correntes de fundamentação. Entretanto, não há fundamentação recíproca. Da leitura das correntes de fundamentação resulta que a coerência argumentativa na estrutura de fundamentação do acórdão paulista é maior do que a estrutura da fundamentação do acórdão gaúcho.

Com efeito, o enfoque deste artigo é examinar a consistência do argumento do consentimento utilizado na interpretação de contendas jurídicas que envolvam direitos da personalidade. Depurados, pois, quais foram os argumentos jurídicos utilizados pelo TJRS (2016), para declarar como lícita a transmissão de informações pessoais entre Facebook e Lulu, resta analisar as implicações jurídicas do consentimento pelo titular do uso dos seus direitos da personalidade, pois o próprio TJRS confirma que "cumpre registrar que o fundamento do pedido indenizatório formulado pelo autor em face do requerido é a importação das informações da rede social Facebook ao aplicativo Luluvise, sem prévia autorização".

solidariamente pela reparação prevista nesta e nas seções anteriores. $\S 2^{\circ}$ Sendo o dano causado por componente ou peça incorporada ao produto ou serviço, são responsáveis solidários seu fabricante, construtor ou importador e o que realizou a incorporação". 


\section{DIGNIDADE DA PESSOA HUMANA, AUTONOMIA DA VONTADE, AUTONOMIA PRIVADA E A DECISÃO GAÚCHA DO CASO "LULU"}

É irrefutável afirmar que atualmente a tendência dos ordenamentos jurídicos é o reconhecimento do ser humano como centro e fim do direito ${ }^{14}$. Esta propensão encontra-se pautada, entre outros motivos, na reação dos Estados democráticos após a traumática experiência da ideologia nazifascista. As mudanças políticas, econômicas e sociais produzidas pelas duas Guerras Mundiais se refletiram de forma imediata nas Declarações de Direitos, principalmente na Declaração Universal de Direitos Humanos, aprovada pela Assembleia Geral das Nações Unidas, em 10 de dezembro de $1948^{15}$. A pessoa humana passou a merecer valorações cardinais para o Direito, outorgando-se elevada importância à personalidade, corroborando-se a ideia de que é a pessoa a figura mais relevante para a Sociedade. Emergiu, neste contexto, o fenômeno que a doutrina autorizada denominada de "repersonalização do Direito", que se traduziu, entre outros efeitos, na inserção na Constituição de matérias que antes eram exclusiva dos fechados Códigos Civis, e a adoção pelos ordenamentos jurídicos de direitos humanos como diretrizes essenciais do Estado. Foram estes incorporados nas Constituições como direitos e garantias fundamentais dedicados a proteger a pessoa humana. Neste sentido, as circunstâncias históricas, sociais e políticas levaram à proteção da personalidade do ser humano, e a consequente adoção pelos Estados de um valor ${ }^{16}$

${ }^{14}$ À guisa de ilustração, a Constituição da República Italiana, de 27 de dezembro de 1947, adotou esta perspectiva no artigo $3^{\circ}$. "Tutti $i$ cittadini hanno pari dignità sociale e sono eguali davanti alla legge, senza distinzione di sesso, di razza, di lingua, di religione, di opinioni politiche, di condizioni personali e sociali".

Na mesma linha, a Lei Fundamental de Bonn, de 23 de maio de 1949, tem acolhimento formal do valor dignidade da pessoa humana no artigo 1.1: "A dignidade humana é intangível. Respeitá-la e protegê-la é obrigação de todos os poderes estatais" (tradução nossa).

Não destoante, a Constituição da República Portuguesa, de 25 de Abril de 1976, proclama a dignidade no seu art. $1^{\circ}$ : "Portugal é uma República soberana, baseada na dignidade da pessoa humana e na vontade popular e empenhada na construção de uma sociedade livre, justa e solidária”.

Com a mesma inteligência, a Constituição Espanhola, de 29 de Dezembro de 1978, dispõe sobre a dignidade no art. 10.1: "La dignidad de la persona, los derechos inviolables que le son inherentes, el libre desarrollo de la personalidad, el respeto a la ley y a los derechos de los demás son fundamento del orden politico y de la paz social".

${ }^{15}$ No preâmbulo declarou "Considerando que o reconhecimento da dignidade inerente a todos os membros da família humana e de seus direitos iguais e inalienáveis é o fundamento da liberdade, da justiça e da paz no mundo", completando o raciocínio no artigo $1^{\circ}$. "Todas as pessoas nascem livres e iguais em dignidade e direitos. São dotadas de razão e consciência e devem agir em relação umas às outras com espírito de fraternidade".

${ }^{16}$ É oportuno comentar, de modo breve, a preferência de denominar a dignidade humana como valor. É certo que se constuma conferir aos conceitos "valor" e "princípio", um caráter prescritivo, mas também é certo que as divergências surgem quando se examina a natureza desta prescritividade. A principal dificuldade neste debate é a tradução destes nas formalizações normativas do Estado, no momento da concessão de maior ou menor relevância jurídica para aqueles que estão insetos no texto constitucional. Por esse motivo surgiu a ideia de que os valores só têm eficácia interpretativa, porque são normas programáticas, simples diretrizes ou declarações retóricas, sem valor vinculativo, identificados como padrões de legitimação da ordem jurídica, e não como parâmetros da legitimidade dos atos jurídicos e que pertencem ao campo axiológico. Nada obstante, o conceito de valores constitucionais oferecido por PÉREZ LUÑO (1987) que indica que eles têm uma tripla dimensão: fundamentadora, orientadora e crítica. Além disso, os valores normalmente não contêm especificações sobre os pressupostos que devem ser aplicados, nem sobre as consequências jurídicas que se devem seguir para a sua implementação. Por conseguinte, os valores formam o contexto histórico-espiritual da interpretação da Constituição e, em particular, a interpretação e aplicação dos direitos fundamentais. Os princípios, por sua vez, têm eficácia normativa e interpretativa, são conceitos deontológicos e podem agir simultânea ou sucessivamente, como: critérios hermenêuticos (principia cognoscendi), para revelar, interpretar e aplicar as restantes normas jurídicas; como fontes de direito (principia essendi) compreendendo elementos normativos ou partes dentro do sistema; ou como padrões de avaliação (prima principia), ou seja, como axiomas ou postulados axiológicos que devem inspirar toda a ordem jurídica (PÉREZ LUÑO, 1987)). No entanto, como bem delimita Zoco Zabala (2003) na medida em que, como que o juiz conduza uma atividade interpretativa-criadora, completando as extremidades da norma não previstas pelo legislador, também projeta o valor na norma de decisão. Essa linha de pensamento aqui descrita leva ao entendimento de que a abordagem prescritiva do valor, que seria feita primeiramente pelo legislador, pode alcançar sua eficácia jurídica na interpretação dada a qualquer texto normativo quando feita pelo Poder Judiciário. Por isso se 
básico enraizado e encontradiço em qualquer Sociedade plural e democrática: a dignidade da pessoa humana como fundamento da Constituição.

Com efeito, é conveniente recordar que a relevância da Constituição, antes deste período, direcionava-se para o documento político que ela representava. Após as duas Grandes Guerras Mundiais o texto constitucional adquiriu verdadeira força normativa, e se impôs como instrumento reitor do ordenamento jurídico do Estado como o texto nomartivo-jurídico superior (HESSE, 1983). A garantia de eficácia jurídica dos direitos baseados na dignidade da pessoa humana não reclamava, exclusivamente, uma mera fixação de dispositivos normativos, mas, sobretudo, uma atualização do ordenamento jurídico. Dito ordenamento jurídico, por tanto, necessitou ser formulado e declarado vinculante pelos poderes estatais em toda sua amplitude, devendo ser concretizada e assegurada sua observância, circunstâncias essas que foram possíveis graças à força normativa que alcançou a Constituição.

Neste contexto, é irretorquível interpretar que a alocação do princípio democrático na base do processo de formação da vontade do Estado legitimou a mencionada positivação da dignidade da pessoa humana. (VESSONI, 2005). De fato, as Constituições democráticas situam o sujeito como emissor e destinatário do Direito, estabelecem a dignidade da pessoa humana como seu principal fundamento e como premissa antropológico-cultural para elevar a democracia como uma consequência orgânica. (HÄBERLE, 1997). É indubitável convergir, portanto, que a força normativa adquirida pela Constituição permitiu, pois, que a teorização da dignidade da pessoa humana se convertesse em uma realidade jurídica. (HESSE,1983).

Não obstante a inserção e a importância formal da dignidade humana na Constituição contemporânea, tarefa árdua é identificar seu âmbito de configuração material. Isso porque, como aduz Pérez Luño (2005), parece ser tributo inexorável dos conceitos e categorias mais recorrentes da teoria jurídica padecer de um déficit de intenção conceitual proporcionalmente inverso a sua extensão de uso. O constitucionalismo brasileiro incluiu a dignidade da pessoa humana como fundamento da República Federativa do Brasil no art. $1^{\circ}$, III ${ }^{17}$. Ingo Sarlet (2004) e Luís Roberto Barroso (2013) se propuseram a dialogar com o texto constitucional para pugnar por uma configuração jurídico-constitucional deste aludido fundamento.

Ingo Sarlet (2004, p.41) admite que dizer o que é dignidade é mais difícil do que desvendar o que ela não é. Por isso advoga por um conceito em construção e em desenvolvimento. Inicialmente recorre ao sentido moral (estoico) e socio-político (clássico) para situar a concepção mais remota dignidade. Comenta, igualmente, sobre a perspectiva tomista de dignitas humana, que une a dignidade do ser humano à sua inata capacidade de autodeterminação para afirmar sua exisência a partir da sua própria autonomia. Não se olvida da proposta racionalista de Pico della Mirandola, que imputa a racionalidade como inerente ao ser humano como a qualidade que possibilita a construção com liberdade e independência da sua própria existência e de seu destino. Recorda a teorização kantiana, para ressaltar que a autonomia da vontade pode ser a "faculdade de determinar a si mesmo e agir em conformidade com a representação de certas leis, é um atributo apenas encontrado nos seres racionais, constituindo-se no fundamento da dignidade da

afirma que os valores, por sua generalidade, permitem uma grande variedade de conversões interpretativo-normativas, enquanto os princípios prefiguram as possibilidades de sua transmutação em normas. Esses conceitos, valor e princípio, são diferentes desde um aspecto meramente quantitativo-gradativo (abstração) e não qualitativo-eficacial (eficácia jurídica). Em sentido semelhante, PÉREZ LUÑO (2005) afirma que a recepção constitucional do valor conecta sua normatividade jurídica à sua prescritividade ética.

17 “Art. $1^{\circ}$ A República Federativa do Brasil, formada pela união indissolúvel dos Estados e Municípios e do Distrito Federal, constitui-se em Estado Democrático de Direito e tem como fundamentos: [...] III - a dignidade da pessoa humana;" 
natureza humana" (SARLET, 2004, p.33). Ainda descreve a dimensão histórico-cultural da dignidade presente em Hegel. Não deixa de sublinhar uma perspectiva ontológica e instrumental de dignidade. Todavia, ao seu juízo, o elemento nuclear da noção de dignidade da pessoa humana parece ser retirado primordialmente da proposta kantiana, que se centra na autonomia e na autodeterminação de cada pessoa (SARLET, 2004, p. 45). A esta dimensão "natural" de dignidade se soma a dimensão cultural, pois as pessoas se complementam e interagem. Defende, portanto, uma dimensão dúplice de dignidade, vinculada à expressão da autonomia da pessoa humana (autodeterminação) e à necessidade de sua proteção (assistência). Identifica, portanto, uma proposta simultaneamente negativa (defensiva) e positiva (prestacional) da dignidade da pessoa humana ao conceituá-la como:

a qualidade intrínseca e distintiva reconhecida em cada ser humano que o faz merecedor do mesmo respeito e consideração por parte do Estado e da comunidade, implicando, neste sentido, um complexo de direitos e deveres fundamentais que assegurem a pessoa tanto contra todo e qualquer ato de cunho degradante e desumano, como venham a lhe garantir as condições existenciais mínimas para uma vida saudável, além de propiciar e promover sua participação ativa e co-responsável nos destinos da própria existência e da vida em comunhão com os demais seres humanos". (SARLET, 2004, p.60).

Por sua vez, na conceituação de dignidade da pessoa humana Luís Roberto Barroso (2013, p.62) aponta duas dimensões: "uma interna, que expressa no valor intrínseco ou próprio de cada indivíduo; e outra externa, representando seus direitos, aspirações e responsabilidades, assim como os correlatos deveres de terceiros". Barroso (2013) traça alguns conceitos kantianos para elucidar a importância desta filosofia para o conceito de dignidade e autonomia. Admite que a autonomia está ligada à vontade livre. A autonomia deflui da autodeterminação, do autogoverno, não vinculada a uma vontade heterônoma. E a dignidade, nesta perspectiva kantiana, tem como um dos seus fundamentos a autonomia.

Barrosso (2013) identifica uma proposta de conteúdo tripartite da dignidade. Há um (i) valor intrínseco-ontológico, ligado à natureza do ser, composto "por um conjunto de características que são inerentes e comuns a todos os seres humanos, e que lhe confere um status especial e superior no mundo, distinto de outras espécies" (BARROSO, 2013, p. 76). No valor intrínseco Barroso (2013) inclui, além da igualdade, alguns direitos da personalidade, como o direito à vida, o direito à integridade física e o direito à integridade psíquica. Neste direito, na nossa tradição, estão compreendidos o direito à honra, o direito à própria imagem, o direito à vida privada $\mathrm{e} o$ direito à intimidade.

Barroso (2013, p. 81) também inclui no conteúdo da dignidade da pessoa humana a (ii) autonomia, como "elemento ético". É no contexto da autonomia que se desenvolve a autodeterminação. Recorda da autonomia moral kantiana (desvicunlação de influências heterônomas), contudo, aposta na autonomia pessoal, detalhada pela razão, independência e escolha. A autonomia consiste na "capacidade de alguém tomar decisões e de fazer escolhas pessoais ao longo da vida, baseadas na sua própria concepção de bem, sem influências externas indevidas" (BARROSO, 2013, p. 82). Desta decorrem alguns direitos fundamentais, como as liberdades básicas (autonomia privada) e o direito à participação política (autonomia pública). Sobre a autonomia privada, um dos objetos deste texto, Barroso (2013, p. 83) exemplifica a concepção estadunidense, para reforçar que "significa autogoverno do indivíduo".

O (iii) valor comunitário, para Barroso (2013), reproduz o "elemento social da dignidade", a sua face relacional. Neste elemento da dignidade estão contidos os valores compartilhados, as normas impostas pelo Estado. Estão dentro do valor comunitário os papéis da comunidade e do Estado que projetam metas coletivas e problematizam as restrições aos direitos e liberdades individuais. 
Com efeito, é forçoso inferir que tanto a concepção ambivalente de Ingo Sarlet (2004) como a concepção tripartite de Barroso (2013) incluem a autonomia como um dos elementos da dignidade da pessoa humana. Barroso (2013) ressalta, inequívoca e textualmente, como elementos da dignidade da pessoa humana os direitos da personalidade tensionados nos casos do aplivativo Lulu: direito à honra, direito à imagem e direito à vida privada/intimidade.

De fato, é de se estimular que o Estado deve-se propor a materializar a igualdade entre os seres humanos, porque integram a sociedade como pessoas; que o Estado deve oferecer a garantia da independência e de autonomia do ser humano, de maneira que impeça toda coação ilícita externa ao livre desenvolvimento da personalidade, como também toda ação que implique em sua degradação. Compete, pois, ao Estado Constitucional conferir proteção aos direitos inalienáveis do ser humano e promover garantias fundamentais para que nenhum ser humano se desenvolva em condições desumanas. A dignidade da pessoa humana como um dos fundamentos da República Federativa do Brasil, confessadamente um Estado Democrático de Direito, implica reconhecer, sem transcendências ou metafísicas, que o ser humano é o limite e o fundamento do domínio político do Estado (homo noumenon). (CANOTILHO, 2003, p. 225).

Nada obstante, em que pese o ser humano ter adquirido esta importância no ordenamento jurídico-constitucional (ser fundamento e limite do poder político), é oportuno ressaltar que a dignidade da pessoa humana não converte o sujeito em um ser ilimitado em sua autonomia. $\mathrm{O}$ próprio valor da dignidade da pessoa humana pode limitar a autonomia privada. Antes de sufragar esta afirmação, convém diferenciar a denominação de autonomia da vontade e autonomia privada.

É usual contextualizar os temas de Direito Privado com algum instituto que tenha correspondência no direito romano. Ana Prata (1982, p. 7-12), por exemplo, recorda a intrínseca vinculação que tinha o conceito de autonomia com os de sujeito jurídico e de propiedade no direito romano. Christian Baldus (2011), por seu turno, aduz que é no direito romano que se vislumbra um indício histórico de que a tese da autonomia (mas não os seus fundamentos metajurídicos) foi desenvolvida em Roma, embora apenas raramente problematizada. Tais indícios provém do respeito à liberdade e à propriedade, da formação contratual e das disposições testamentárias. Érico de Pina Cabral (2011) também recorda a vinculação da autonomia com os negócios não formais da quotidiano dos romanos (bona fides) e nos negócios formais, como no contrato e no testamento, passando a interpretação ter importância ao se querer compreender a verba por meio da voluntas individual.

Não obstante, a construção do conceito moderno de autonomia se remonta à França, da passagem do século XVIII para meados do século XIX (ARAÚJO, 2006; FACHIN, 2012). Os propósitos da Revolução Francesa subsidiaram a construção jurídica do consenso, resultando que a idealização da autonomia da vontade inspirasse propostas políticas, jurídicas e sociais, com base na ideia "contratualista" (ARAÚJO, 2006).

O termo autonomia da vontade, segundo Roxana Borges (2005a) foi incluído na perspectiva jurídica em que a vontade era, por si só, fundamento de direitos. Segundo a tese dos voluntaristas, a declaração de vontade é a que gera atos e negócios jurídicos. A vontade, portanto, constituía-se um elemento central na teoria dos atos jurídicos. Um dos pilares da defesa da autonomia da vontade foi a ideia da indissociação entre a pessoa e a sua vontade, a vontade como própria expressão psíquica da pessoa. Neste sentido, forjou-se o argumento do consentimento ("consensualismo") em que se reconhecia força jurídica a um acordo de vontades, criando efeitos jurídicos. Um dos grandes exemplos desta assertiva é o artigo 1.134, del Código Civil Napoleônico, promulgado em 1804, o qual solenizava a preponderância do papel do consentimento, afirmando que o contrato deveria ser convencionado de boa-fé, era lei entre as partes, podendo ser 
revogado apenas por mútuo consentimento, ou por causas fixadas em lei: "Les conventions légalement formées tiennent lieu de loi à ceux qui les ont faites. Elles ne peuvent être révoquées que de leur consentement mutuel, ou pour les causes que la loi autorise. Elles doivent être exécutées de bonne foi”. (FRANCE, 2004). Esta formulação foi reproduzida no art. 702 do Código Civil português de 1867; no art. 1.091 do Código Civil espanhol de 1889 e no art. 1.933 do Esboço de Código Civil de Teixeira de Freitas (RODRIGUES JUNIOR, 2011).

De fato, admitia-se que cabia aos particulares, com esteio na vontade, instituir as regras contratuais e as consequências a serem levadas a cabo, sem a interferência do poder público (BERTI, 2014). A autonomia da vontade se configurava, pois, no poder de "criar e regular os efeitos jurídicos de sua contratação, sem intervenção externa: o contrato era uma esfera de livre atuação dos particulares" (BERTI, 2014, p. 69-94). Não se pode olvidar que este dogma da vontade era estruturado com o pressuposto da igualdade entre os contratantes. Prevalente na época, portanto, a premissa da igualdade formal entre as partes (ARAÚJO, 2006). O conceito de autonomia era caracterizado como demonstração do poder jurígeno dos particulares (ARAÚJO, 2006; NETO, 2011). A partir desta compreensão da autonomia da vontade, o Direito teria de assegurar que a vontade criadora do contrato fosse livre de vícios ou de defeitos, o que deu lugar às teorizações da liberdade contratual, da força obrigatória dos contratos e dos vícios do consentimento (MARQUES, 2016).

Luigi Ferri (2001), por seu turno, critica a autonomia da vontade. Aduz que quem assim o faz, dá relevo à vontade real ou psicológica dos sujeitos, que supostamente é a raiz dos negócios e efeitos jurídicos. Ao se interpretar um contrato, a hermenêutica teria de precisar a vontade dos contratantes, não desligando o negócio jurídico do momento psicológico da iniciativa contratual (BERTI, 2014). A prevalecer esta ótica, o estado anímico dos pactuantes para a celebração do contrato seria decisivo, priorizada uma conotação mais subjetiva (ADOLFO; PIRES, 2015). E por isso se deduzia que a autonomia da vontade esteve conectada a elementos predominantemente subjetivos, baseados na psique dos contratantes (BERTI, 2014), o que nos remontaria a um modo de interpretação que não dispensa uma análise psicológica, presente, por exemplo, na "divinação" levantada por Friedrich Daniel Ernst Schleiermacher. (RUEDELL, 2012, 2013; DILTHEY, 1900) $)^{18}$.

Por sua vez, a teoria da autonomia privada questionou o dogma voluntarista ao advogar que o mero consentimento não é capaz de criar direito. Consoante pugna Francisco dos Santos Amaral Neto (2011), a autonomia privada "problematiza as relações entre a vontade e a norma". Se acentuada a primeira, prevalecerá a natureza subjetiva da discussão, em que se dá predileção

\footnotetext{
${ }^{18}$ Esta postura leva a hermenêutica contratual às teorizações do teólogo protestante Friedrich Schleiermacher (17681834), considerado um dos precursores da hermenêutica moderna (RUEDELL, 2012, 2013; DILTHEY, 1900). Friedrich Schleiermacher teoriza a hermenêutica sob duas condições: a consciência livre e criadora do sujeito e a linguagem. Isso porque o discurso tem uma dupla relação: para o todo da linguagem e para o todo do pensamento do autor. Autor e linguagem, portanto, são inseparáveis na constituição de um discurso, e por isso estas duas perspectivas de interpretação e compreensão são exigidas e igualmente importantes. Friedrich Schleiermacher completou a exegese gramatical com a interpretação psicológica, a que se referiu como divinatória (divinação). A interpretação psicológica se refere ao autor e a seu estilo. O autor não é uma figura abstrata, mas situado num contexto, que, de alguma forma, o constitui. A hermenêutica deveria aproximar, portanto, o liame entre o estilo/tendência e seu autor. A interpretação não se orientaria apenas para o texto, sobretudo, para o diálogo com o seu autor. Com este proceder, o hermeneuta reencontraria a sua intenção originária (projeto originário), os motivos que o levaram a escrever (Divinação). Há de se unir a literalidade da interpretação gramatical potencializada pela "interpretação psicológica". O hermeneuta haveria de buscar as circunstâncias concretas que conformaram a redação do texto, recriando a mente do autor de acordo com os influxos socais que marcaram sua existência. A divinação era, pois, o esforço de refazer o projeto criador e imaginário do autor: a tentativa de refazer a singularidade estilística de uma obra (interpretação técnica) e de seu autor (interpretação psicológica). Há, pois, uma dependência mútua entre o iter gramatical e o psicológico.
} 
à vontade dos agentes. Se maximizada a segunda, verificar-se-á os interesses gerais da comunidade, potencializados pelo caráter objetivo da declaração normativa.

Com a autonomia privada se defendeu que a vontade, em si mesma, é interna ao sujeito e não pode ser reconhecível por outra pessoa e pelo ordenamento jurídico, existindo unicamente para a consciência da própria pessoa ${ }^{19}$. (BORGES, 2005a, p. 52; CABRAL, 2011). Por este motivo é que se começou a empregar o termo manifestação ou declaração da vontade e não somente vontade. Somente seria legítimo o consentimento previsto no ordenamento jurídico ou que não o contrariasse. (BORGES, 2005b, p. 73). O negócio jurídico não se origina simplesmente da manifestação da vontade, pois tal concepção procede de um primado individualista, que considera o sujeito fora do contexto social. Não há como estabelecer, portanto, uma conexão automática entre a vontade e os efeitos jurídicos. Com a autonomia privada se indaga, pois, a vontade individual onipotente, a qual poderia transcender a consequências jurídicas desprovidas de limites. A autonomia privada, pelo contrário, sempre estará condicionada pela ordem jurídica, que estabelece a forma, o conteúdo, a capacidade e a legitimidade dos sujeitos. A vontade e a sua declaração são requisitos para a conformação do negócio jurídico, mas não são condições suficentes de validade (BORGES, 2005b).

Esta linha de pensamento vislumbra a declaração ou manifestação de vontade como um fato objetivo, ou a própria lei como fonte dos negócios e efeitos jurídicos. O início desta mudança de entendimento, da autonomia da vontade para a autonomia privada, coincide com o avanço do Estado Liberal para o Estado Intervencionista (FERRI, 2001; NETO, 2011; ADOLFO; PIRES, 2015). Não sem razão Natália Berti (2014) observa que o racionalismo, o individualismo e o formalismo do Direito Civil cedem ante o pluralismo de fontes, à descodificação do Direito Civil, motivados pela humanização e repersonalização dos institutos, com a consequente despatrimonialização e constitucionalização do Direito Civil. Estas circunstâncias históricas levam a uma releitura à luz dos dispositivos constitucionais dos dogmas clássicos do Direito Civil, como a pessoa, a família, o patrimônio, a propriedade (BERTI, 2014), e o contrato; das fontes do Direito Civil e da atuação do Estado; e de grupos intermediários (NETO, 2011).

Com o advento do Estado Social, configurou-se a constatação de que substancialmente as pessoas estão situações de desigualdade social e, por isso, as manifestações volitivas devem ter um controle de juridicidade. A compreensão contemporânea sobre a autonomia privada há de ser inserida no âmbito de um Estado Constitucional que assegura a expressão da liberdade dos particulares, mas amolda seu perfil em consonância com os demais princípios que regem as relações de direito privado (FACHIN, 2012). Este raciocínio de Luis Edson Fachin (2012) é sustentado com a consideração de que não se pode mais elevar a autonomia da vontade como dogma "[...] dotada apenas de tênues limites externos, mas de uma autonomia para a regulamentação de interesses pelos próprios particulares, que se insere em um conjunto mais amplo de valores e princípios que a contemplam”.

As relações contratuais atingiram o século XX com intuitos guiados para e pela massificação. Não se pactuaram contratos em que as partes estivessem em posição de igualdade perante

\footnotetext{
${ }^{19}$ Henrique Garbellini Carnio (2012), no interessante texto "O pensamento Kelseneano e o conceito de vontade no Direito Privado", observa que Kelsen se esmerou em definir "vontade" na terminologia jurídica em contraste com o conceito psicológico de vontade. Neste sentido, não poderia ser sinônimo de vontade uma "representação", fenômenos de ordem exterior, substratos de fato. O que interessaria ao Direito era conectar os substratos exteriores do fato e os sujeitos. E se descobrir se um fato exterior foi "querido" ou não pelo sujeito. O conceito jurídico de vontade, portanto, estreitaria o nexo entre o sujeito e os acontecimentos do mundo exterior. Com efeito, todos os processos puramente interiores do sujeito sem relação com o mundo externo seria de competência da psicologia. Os acontecimentos exteriores do mundo físico, substratos de fato podem ser entendidos como produzidos pela vontade. E é neste contexto que Kelsen afirmaria que o conceito de vontade no direito privado estaria radicado na teoria do negóio jurídico.
} 
o direito e a sociedade, que discutissem individual e livremente as cláusulas de seu acordo de vontade. (MARQUES, 2016, p. 71). Surgiram diversas relações jurídicas, produzidas pelo tráfego de massa, que demandaram uma nova interpretação do dogma da autonomia da vontade. As contratações em massa (contratos standard ou contratos de adesão) estipularam condições gerais, módulos e formulários redigidos por uma parte para uma massa homogênea e indiferenciada de contrapartes (contratos de massa). Configurou-se, portanto, numa contratação impessoal e acelerada. A aceitação (do consumidor) se reduziu a uma adesão passiva ao que estava previamente entabulado. Esta pré-redação unilateral pode levar aos que detêm a posição negocial de "elaboradores da lex privada e os que a ela se submetem, podendo apenas aderir à vontade manifestada pelo outro contratante". (MARQUES, 2016, p. 73). As empresas com superioridade econômica ou técnica têm o objetivo de racionalizar, simplificar, padronizar a sua atividade com ditames contratuais uniformes e homegêneas, reduzindo custos, prevendo lucros e distribuindo os riscos (BERTI, 2014; MARQUES, 2016).

É nesta realidade que se propugnou a funcionalização dos institutos jurídicos do Direito Privado, conforme explana Francisco dos Santos Amaral Neto (2011). Do Direito e da Sociedade erigem o interesse pela efetividade das leis e dos institutos com relação ao controle social agregado à organização e direção da sociedade, por meio "do exercício de funções distributivas, promocionais ou inovadoras, abandonando-se a costumeira função repressiva, principalmente na relação do Direito com a Economia" (NETO, 2011, p. 117-144). A inserção da função econômico-social dos institutos jurídicos decorre, pois, da confluência das tendências axiológicas contemporâneas que levam à chamada economia dirigida (NETO, 2011). A releitura orientada para a função econômico-social dos institutos jurídicos, parte prefacialmente da propriedade, mas chega ao contrato. E é precisamente o contrato, um instrumento típico e inequívoco de manifestação da autonomia privada, que a teoria funcionalização dos institutos jurídicos teve apoio. Como exemplos, Francisco dos Santos Amaral Neto (2011) cita o Código Civil italiano de 1942 (art. 1.322), o Código Civil português de 1966 (art. 280. ${ }^{\circ}$ e art. 405..$^{\circ}$ ), e o Código Civil brasileiro de 2002 (art. 421: "A liberdade de contratar será exercida em razão e nos limites da função social do contrato"). Esta função econômico-social demonstra a preocupação com a efetividade dos institutos, e, quanto à autonomia privada:

\begin{abstract}
no caso particular da autonomia privada, significa que o reconhecimento e o exercício desse poder, ao realizar-se na promoção da livre circulação de bens e serviços e na auto-regulamentação das relações disso decorrentes, condiciona-se à utilidade social que tal circulação possa representar, por ser o meio mais adequado à satisfação das necessidades sociais, com vistas ao bem-comum e ao seu objetivo de igualdade material para todos em face das exigências de justiça social, ideia essa que se desenvolve paralelamente à evolução do Estado moderno como ente ou legislador racional. (NETO, 2011, p. 117 - 144).
\end{abstract}

O dogma da vontade, portanto, gestado para o sistema liberal individualista e baseado em pactos de caráter pessoal, converte-se em inexoravelmente inadequado para a interpretação e aplicação dos contratos na atualidade. Contudo, esta forma de interpretação dos contratos parecer ser a que foi empregada pelo TJRS no caso Lulu. O TJRS acatou o argumento do consentimento defendido pelo Facebook, revestido de autonomia da vontade. Esta conclusão é retirada da afirmação do acórdão de que contratualmente o autor da ação, ao se registrar no Facebook, havia autorizado que as suas imagens e os seus dados pessoais poderiam ser utilizados para qualquer finalidade.

O TJRS, portanto, não levou em consideração a indiscutível desigualdade de facto contratual da relação Facebook-Particular. A desigualdade contratual se baseia no fato de que não houve discutissão individual e livre sobre as cláusulas do "acordo de vontade". Nos termos de uso do Facebook constam condições gerais pré-estabelecidas, redigidas para uma massa homo- 
gênea e indiferenciada de contrapartes. Configurou-se uma contratação indisfarçavelmente impessoal. A aceitação do autor se reduziu a uma adesão passiva ao que estava previamente estipulado. O Facebook se arvorou na posição negocial de "elaborador da lex privada", pois, sem denso esforço hermenêutico, é flagrante a sua superioridade econômica e técnica perante o autor da ação/contratante. Diante deste contexto, resta confluir que o TJRS não procedeu uma leitura orientada para a função econômico-social do contrato prevista não só na legislação civil (art. 421, CC-02) como também na consumerista (art. 54, CDC-90). Por este fato, e pela construção histórica da autonomia da vontade versus autonomia privada, é plausível afirmar que o entendimento do TJRS nesta apelação cível se baseou numa concepção contratual norteada pelo dogma da autonomia da vontade. $\mathrm{O}$ argumento do consentimento utilizado pelo TJRS, pautado no dogma da autonomia da vontade, é inconsistente, pois contraria a lógica do sistema jurídicoconstitucional vigente.

Ademais, cabe sublinhar que que o TJRS reconheceu haver violações aos direitos da personalidade do autor, mas atribuiu esta responsabilidade exclusivamente à Luluvise Incorporation. Afirmou ainda que os dados usados são "dados públicos Facebook, acessíveis por qualquer pessoa":

No caso concreto, conforme se depreende das cópias de telas do aplicativo Luluvise
(fls. 13/15), as informações que foram utilizadas para que as mulheres pudessem re-
alizar avaliação de seus amigos foram, unicamente, as que constituem dados públi-
cos.
Nesse contexto, não há falar em compartilhamento indevido de dados pelo Facebook,
como alega a parte autora.
[...]
Se o aplicativo Luluvise, a partir do uso de dados públicos do Facebook, acessíveis
por qualquer pessoa, criou um perfil não autorizado pela parte autora, possibilitando
que terceiros compartilhem informações não autorizadas, anônimas e ofensivas a sua
intimidade, por este fato deverá responder apenas a empresa que gerencia o referido
aplicativo.

Aqui radicam mais duas inconsistências argumentativas. Uma voltada para a irresponsabilidade do Facebook pela transmissão de dados. Outra pelo destino dos dados pessoais e imagens do autor. A lógica interpretativa desta situação há de ser racionalizada a partir do binômio causalidade-finalidade. (ARAÚJO, 2006).

Em que pese o fato de não haver influência direta do Facebook nos comentários ofensivos realizados dentro da plataforma do aplicativo Lulu, é inegável a potencialização do impacto que a organização e a sistematização dos dados pessoais feitas pelo Facebook gera na divulgação e na facilitação da localização destes dados. Se não houvesse uma compilação completa, se não houvesse a organização e a sistematização dos dados pessoais e imagens pelo Facebook, o aplicativo Lulu teria de buscá-los em um emaranhado de páginas interligadas e interconectadas. Encontrar os dados pessoais e as imagens sem este "indexador auxiliar"/ Facebook (causalidade), a busca e o êxito do aplicativo (finalidade) se tornaria inexoravelmente mais onerosa. Tratar-seia, efetivamente, de uma atividade de dificuldade agravada, com chances reduzidas de sucesso, considerando-se a multiplicidade de dados espalhados em toda a Internet e a ausência de um indexador/transmissor/sistematizador/organizador/facilitador de acesso específico acerca dos dados pessoais e imagens que se efetivamente transmitiu.

A constante e instantânea organização e sistematização de dados pessoais e imagens do autor é o que permitiu a sua transmissão fidedigna para que as reconhecidas violações aos direitos da personalidade fossem perpretadas. Sem a indexação/organização/sistematização/facilitação/ transmissão do Facebook, o aplicativo Lulu teria que se socorrer de um grande repositório de 
informações sem estrutura lógica que facilitasse os dados e imagens do autor. Em suma, o Facebook pode ser o configurador da causa para a finalidade do aplicativo Lulu. O argumento de que os dados pessoais e imagens do autor são públicos, acessíveis a todos, também é inconsistente, pois contraria a própria lógica da relação de indexação/organização/sistematização/facilitação/ transmissão do Facebook com o Lulu.

A última inconsistência argumentativa se dá pelo fato do reconhecimento pelo próprio TJRS que houve violações aos direitos da personalidade do autor. A inconsistência é que constam nos termos de uso do Facebook condições gerais pré-redigidas que o autor havia autorizado que as suas imagens e os seus dados pessoais poderiam ser utilizados para qualquer finalidade. Entretanto, "os negócios com conteúdo não patrimonial, mais do que os outros, encontram seus limites no princípio constitucional da dignidade da pessoa humana" (BORGES; 2005a, p. 55; 2005b, p. 75).

Não se pode admitir que um dos contratantes seja reduzido à condição de mero objeto da pretensão contratual, com iniludível ausência de respeito à sua condição de pessoa. E a condição de pessoa foi violada, pois houve reconhecimento pelo TJRS de que foram violados os direitos da personalidade do autor, os quais integram o valor intrínseco-ontológico, ligado à natureza do ser (BARROSO, 2013). Ainda que considerada a autonomia privada das partes, vulnera-se a ordem jurídico-constitucional baseada na dignidade da pessoa humana se o ser humano é tido como um mero objeto a disposição de qualquer outro, sem limites jurídicos.

É neste contexto que a autonomia privada é um elemento da dignidade da pessoa humana, mas não é o único; quer se utilize a proposta ambivalente de dignidade da pessoa humana de Ingo Sarlet (2004), quer se utilize a concepção tripartite de Barroso (2013). A autonomia privada pode ser limitada pelo valor da dignidade da pessoa humana (BERTI, 2014), para adequar em determinadas hipóteses em que não pode ser invocada para criar ou manter uma relação jurídica da qual se deriva um desprezo ou indiferença da condição humana do indivíduo, como no caso examinado. Não se pode, pois, justificar com o argumento da autonomia privada (ou da superada autonomia da vontade) que um contrato seja válido, legítimo ou lícito quando sua execução provoque uma situação de submissão, dominação ou uma humilhação, de tratamento degradante, aplicada a uma das partes. Com o preceito de que o ser humano é o limite e o fundamento do domínio político do Estado (homo noumenon), da dignidade da pessoa humana há de se extrair o dever de proteção à inviolabilidade moral da pessoa. A dignidade humana na história e na atualidade tem sido o ponto de referência de todas as faculdades que se dirigem ao reconhecimento e à afirmação da dimensão moral da pessoa (PÉREZ LUÑO, 2005). E esta dimensão moral foi representada (também) pelos direitos fundamentais da personalidade (art. $5^{\circ}, \mathrm{V}, \mathrm{X}$; $220, \S 1^{\circ}$ ) e protegida pelo Código Civil brasileiro de 2002.

A prodigalidade em dedicar um capítulo aos direitos da personalidade unida a topografia na parte geral do Código demonstra uma mudança de paradigmas no direito civil, que eleva a proteção da pessoa humana. "A esta constatação segue uma reelaboração da dogmática civilística, na qual os direitos da personalidade desempenham papel fundamental”. (DONEDA, 2005, p.71).

Por certo, para se ter a vida livre e digna, é necessário dispor de um âmbito de individualidade, isento de interferências em que se possa desenvolver as convicções, resguardando seus pensamentos, sentimentos e fatos (SZANIAWSKI, 2005). Na vida social, tratamos de construir nossa própria personalidade, manifestada pela individualidade. Os bens da personalidade, inequivocamente pautados na autonomia privada, hão de ser entendidos como emancipadores dos seus titulares não se adstringindo aos instrumentos reguladores que desabonam as condutas que lhe são ofensivas. Efetivamente, quem não é capaz de decidir sobre seus assuntos ou não está 
disposto a fazê-lo, e quem não responde sobre suas próprias ações, dificilmente poderá questionar adequada e responsavelmente os assuntos de transcendência geral, pois só em pessoas que pensam, julgam e atuam por si mesmas descansa o potencial de novas ideias, concepções e iniciativas, irrenunciáveis para a sociedade, sem as quais esta, como tempo, haverá de se empobrecer, ou se fossilizar, cultural, econômica e politicamente. É por isso que os direitos da personalidade, que alocam a pessoa como vértice do ordenamento jurídico, foram guindados ao posto fundamentais, pois surgem num contexto de promover a dignidade humana. Mas ao que parece, esta importância jurídico-constitucional dos direitos da personalidade não foi observada na apelação cível n. 0158308-71.2016.8.21.7000, pois o destino/finalidade destes direitos os conduziu a uma reconhecida violação, sem imputar responsabilidade à sua causa(lidade).

\section{CONCLUSÃO}

Com esta pesquisa, podem ser elencadas algumas conclusões.

No primeiro tópico foram expostos os conceitos de coerência e de consistência de Robert Alexy (2006). A partir destes, o artigo se pautou no conceito de coerência apenas no aspecto da estruturação da fundamentação, pois não se avaliou sistemas ou teorias e sim dois dos acórdãos: a decisão do TJRS (2016) e o julgado do TJSP (2015). O motivo eleito para a comparação foi baseado em dois critérios: a colegialidade das decisões e a instância em que chegaram. Além disso, há uma convergência em uma declaração normativa geral nestes tribunais: ambos reconhecem o "argumento consumerista", ou seja, a existência da relação de consumo entre o autor da ação e os fornecedores Facebook e Luluvise Corporation (art. $2^{\circ}$ e $3^{\circ}$, CDC-90). O TJRS adota o argumento consumerista, mas não utiliza a lógica das relações de consumo para as demais correntes de fundamentação de sua decisão. Da leitura das correntes de fundamentação resulta que a coerência argumentativa na estrutura de fundamentação do acórdão paulista é maior do que a estrutura da fundamentação do acórdão gaúcho.

No segundo tópico, constatou-se que pela construção histórica da autonomia da vontade versus autonomia privada, é plausível afirmar que o entendimento do TJRS na apelação cível $\mathrm{n}$. 0158308-71.2016.8.21.7000 se baseou numa concepção contratual norteada pelo dogma da autonomia da vontade. $\mathrm{O}$ argumento do consentimento utilizado pelo TJRS, pautado no dogma da autonomia da vontade, é inconsistente, pois contraria a lógica do sistema jurídico-constitucional vigente.

O argumento de que os dados pessoais e imagens do autor são públicos, acessíveis a todos, também é inconsistente, pois contraria a própria lógica da relação de indexação/organização/ sistematização/facilitação/transmissão do Facebook com o Lulu. É igualmente inconsistente o argumento de que o autor autoriza o destino das suas imagens e dos seus dados pessoais para qualquer finalidade, que consta nos termos de uso do Facebook nas condições gerais pré-redigidas. A autonomia privada é um elemento da dignidade da pessoa humana, mas não é o único; quer se utilize a proposta ambivalente de dignidade da pessoa humana de Ingo Sarlet (2004), quer se utilize a concepção tripartite de Barroso (2013). Não se pode, pois, justificar com o argumento da autonomia privada ou da superada autonomia da vontade que um contrato seja válido, legítimo ou lícito quando sua execução provoque uma situação de submissão, dominação ou uma humilhação, de tratamento degradante, aplicada a uma das partes. Com o preceito de que o ser humano é o limite e o fundamento do domínio político do Estado (homo noumenon), da dignidade da pessoa humana há de se extrair o dever de proteção à inviolabilidade moral da pessoa. 


\section{REFERÊNCIAS}

ADOLFO, Luiz Gonzaga Silva; PIRES, Eduardo. Autonomia privada e suas limitações legais: reflexo da incidência direta dos direitos fundamentais. Revista de Estudos Constitucionais, Hermenêutica e Teoria do Direito (RECHTD), v. 7, n. 2, p. 176-187, maio/ago. 2015.

ALEXY, Robert. Fundamentação jurídica, sistema e coerência. Revista de Direito Privado, v. 25, p. 297-310, jan./mar. 2006.

AMARAL NETO, Francisco dos Santos. A autonomia privada como princípio fundamental da ordem Jurídica - perspectivas estrutural e funcional. Doutrinas Essenciais de Responsabilidade Civil I, v. 1, p. 117-144, out. 2011.

ARAÚJO, Maria Angélica Benetti. Autonomia da vontade no Direito contratual. Revista de Direito Privado, v. 27, p. 279-292, jul./set. 2006.

BALDUS, Christian. Autonomia privada romana. Revista dos Tribunais, v. 904, p. 41-72, fev. 2011.

BERTI, Natália. Da autonomia da vontade à autonomia privada: um enfoque sob o paradigma da pós-modernidade. Revista de Direito Privado, v. 57, p. 69-94, jan./mar. 2014.

BARROSO, Luís Roberto. A dignidade da pessoa humana no Direito Constitucional Contemporâneo. Belo Horizonte: Fórum, 2013.

BORGES, Roxana Cardoso Brasileiro. Disponibilidade dos direitos de personalidade e autonomia privada. São Paulo: Saraiva, 2005.

. Autonomia privada e negócio jurídico. Revista do Curso de Direito da UNIFACS, Porto Alegre, v. 5, p. 69-87, set. 2005.

BRASIL. Constituição da República Federativa do Brasil de 1988. Disponível em: <http:// www.planalto.gov.br/ccivil_03/constituicao/constituicaocompilado.htm>. Acesso em: 15 jun. 2017.

. Lei n. 5.869, de 11 de Janeiro de 1973. Disponível em: <https://www.planalto.gov.br/ ccivil_03/leis/15869.htm>. Acesso em: 15 jun. 2017.

. Lei n. 8.078, de 11 de Setembro de 1990. Disponível em: < http://www.planalto.gov.br/ ccivil_03/leis/L8078compilado.htm>. Acesso em: 15 jun. 2017.

. Lei n. 10.406, de 10 de Janeiro de 2002. Disponível em: <http://www.planalto.gov.br/ ccivil_03/leis/2002/L10406compilada.htm>. Acesso em: 15 jun. 2017.

. Lei n. 13.105, de 16 de Março de 2015. Disponível em: < http://www.planalto.gov.br/ ccivil_03/_ato2015-2018/2015/lei/113105.htm>. Acesso em: 15 jun. 2017.

CABRAL, Érico de Pina. A “autonomia” no Direito Privado. Doutrinas Essenciais Obrigações e Contratos I, v. 3, p. 95-146, jun. 2011.

CANOTILHO, J. J Gomes. Direito Constitucional e Teoria da Constituição. Almedina: Coimbra, 2003.

CARNIO, Henrique Garbellini. O pensamento Kelseneano e o conceito de vontade no Direito Privado. Revista de Direito Privado, v. 51, p. 57-69, Jul./Set. 2012. 
CONJUR. Dano à honra: Facebook deverá excluir perfil do aplicativo Lulu, Consultor Jurídico, 7 de dezembro de 2013. Disponível em: <http://www.conjur.com.br/2013-dez-07/facebook-devera-excluir-perfil-usuario-goiano-aplicativo-lulu $>$ e em: $<$ http://s.conjur.com.br/dl/facebookdevera-excluir-perfil-goian.pdf>. Acesso em: 21 mar. 2017.

DILTHEY, Wilhelm. O Surgimento da Hermenêutica (1900). Numem: revista de estudos e pesquisa da religião, Juiz de Fora, v. 2, n. 1, p. 11-32.

DISTRITO FEDERAL. Ministério Público do Distrito Federal e Territórios (MPDFT). Facebook e Aplicativo "Lulu” são alvo de Inquérito Civil Público, MPDFT, 2 de dezembro de 2013. Disponível em: <http://www.mpdft.mp. br/portal/index.php/comunicacao-menu/noticias/noticias-2013/6563-aplicativo-lulu-e-facebook-sao-alvos-de-inquerito-civil-publico $>$. Acesso em: 21 mar. 2017.

. Tribunal de Justiça do Distrito Federal e Territórios (TJDFT). Processo 004703530.2013.8.07.0001. Ofício, $1^{\text {a }}$ Vara Cível de Brasília, 11 de julho de 2014. Disponível em: $<$ http://tjdf19.tjdft.jus.br/cgi-bin/tjcgi1?NXTPGM=tjhtml105\&SELECAO=1\&ORIGEM=INTER\&CIRCUN=1\&CDNUPROC=20130111849217> . Acesso em: 21 mar. 2017.

Processo 0031665-14.2013.807.0000. Agravo de Instrumento, $6^{a}$ Turma Cível, 19 de dezembro de 2013. Disponível em: <http://s.conjur.com.br/dl/justica-obriga-lulu-retirardados.pdf>. Acesso em: 21 mar. 2017.

DONELA, Danilo. Os direitos da personalidade no Código Civil. Revista da Faculdade de Direito de Campos, ano VI, n. 6, p. 71-99, jun. 2005.

FACHIN, Luiz Edson. Autonomia privada e estipulação contratual. Soluções Práticas, v. 1, p. 321, jan. 2012.

FERRI, Luigi. La autonomía privada. Trad. Luis Sancho Mendizábal. Edición al cuidado de Jose Luis Monereo Pérez. Granada: Editorial Comares, 2001.

FRANCE. Assemblée nationale. 200 ans de Code civil. Disponível em: $<$ http://www.assembleenationale.fr/evenements/code-civil-1804-1.asp>. Acesso em: 27 mar. 2017.

HESSE, Konrad. Escritos de Derecho Constitucional. Trad. Pedro Cruz Villalón. Madrid: Centro de Estudios Constitucionales, 1983.

HÄBERLE, Peter. Libertad, igualdad, fraternidad: 1789 como historia, actualidad y futuro del Estado Constitucional. Trad. Ignacio Gutiérrez Gutiérrez. Madrid: Editorial Trotta, 1997.

MANNARA, Barbara. Como usar o Lulu para avaliar rapazes. Techtudo, 26 nov. 2013. Disponível em: <http://www.techtudo.com.br/dicas-e-tutoriais/noticia/2013/11/como-usar-o-applulu-para-avaliar-rapazes.html>. Acesso em: 20 mar. 2017.

MARQUES, Cláudia Lima. Contratos no Código de Defesa do Consumidor: o novo regime das relações contratuais. 8. ed. São Paulo: RT, 2016.

OLHAR DIGITAL. Aplicativo Lulu volta ao Brasil e permite o acesso de homens, Redação Olhar digital, 13 jul. 2015. Disponível em: $<$ https://olhardigital.uol.com.br/noticia/aplicativolulu-volta-ao-brasil-e-permite-o-acesso-de-homens/49736>. Acesso em: 20 mar 2017.

PRATA, Ana. A Tutela Constitucional da Autonomia Privada. Lisboa: Almedina, 1982.

PÉREZ LUÑO, Antonio-Enrique. Sobre la igualdad en la Constitución Española. Anuario de Filosofía del Derecho, n. 4, p. 133-152, 1987.

. Derechos Humanos, Estado de Derecho y Constitución. Madrid: Tecnos, 2005. 
RUEDELL, Aloísio. Gadamer e a recepção da Hermenêutica de Friedrich Schleiemarcher: uma discussão sobre a interpretação psicológica. Veritas, Porto Alegre, v. 57, n. 3, p. 74-85, set./dez 2012.

. Filosofia e imaginação: uma discussão sobre a hermenêutica de Friedrich Schleiermacher. Problemata Rev. Int. de Filosofia. v. 4, n.1, p. 65-78, 2013.

RIO GRANDE DO SUL. Tribunal de Justiça do Rio Grande do Sul (TJRS). Processo n. 0008981-69.2013.8.21.0109. Sentença, Comarca de Marau, 9 de setembro de 2014. Disponível em: <http://www.tjrs.jus.br/busca/?tb=proc>. Acesso em: 24 mar. 2017.

Processo n. 0008981-69.2013.8.21.0109. Sentença, Comarca de Marau, 18 nov. 2015. Disponível em: <http://www.tjrs.jus.br/busca/?tb=proc>. Acesso em: 24 mar. 2017.

. Processo n. 0158308-71.2016.8.21.7000. Acórdão, 10a Câmara Cível, 12 de maio de 2016. Disponível em: <http://www.tjrs.jus.br/busca/?tb=proc>. Acesso em: 24 mar. 2017.

RODRIGUES JUNIOR, Otávio Luiz. A doutrina do terceiro cúmplice: autonomia da vontade, o princípio res inter alios acta, função social do contrato e a interferência alheia na execução dos negócios jurídicos. Doutrinas Essenciais Obrigações e Contratos, v. 3, p. 1225-1250, jun. 2011.

SÃO PAULO. Tribunal de Justiça do Estado de São Paulo (TJSP). Processo n. 100064747.2014.8.26.0564. Sentença, $8^{a}$ Vara Cível da Comarca de São Bernardo do Campo, 20 de maio de 2014. Disponível em: <http://s.conjur.com.br/dl/sentenca-lulu-indenizacao-danos-morais.pdf $>$. Acesso em: 21 mar. 2017.

. Apelação n. 1000647-47.2014.8.26.0564. Acórdão, $2^{\text {a }}$ Câmara de Direito Pri-

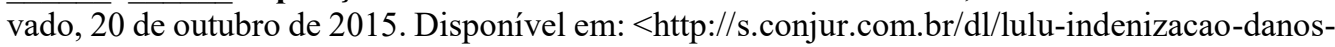
morais.pdf>. Acesso em: 21 mar. 2017.

SARLET, Ingo. Dignidade da pessoa humana e direitos fundamentais na Constituição Federal de 1988. Porto Alegre: Livraria do Advogado, 2002.

SZANIAWSKI, Elimar. Direitos de personalidade e sua tutela. 2. ed. São Paulo: Revista dos Tribunais, 2005.

VESSONI, Elaine Parpinelli Moren. A força normativa da Constituição, Konrad Hesse e a Essência da Constituição, Ferdinand Lassale (comentários bibliográficos). Revista Brasileira de Direito Constitucional, n. 5, p. 360-366, jan./jun. 2005.

ZOCO ZABALA, C. Igualdad en la aplicación de las normas y motivación de sentencias. Barcelona: BOSCH, 2003. 